\title{
Czynniki optymalizacji struktury kapitału. Praktyczna weryfikacja
}

\author{
JOWITA PIATTKOWSKA
}

mgr, Katedra Finansów Przedsiębiorstw i Ubezpieczeń Gospodarczych

Uniwersytet Ekonomiczny w Katowicach

e-mail: jowita.piatkowska@gmail.com

SŁoWA KLUCZOWE struktura kapitału, koszt kapitału, wartość przedsiębiorstwa, optymalna struktura kapitału

StreszCZENIE Problem struktury kapitału jest jednym z głównych problemów decyzyjnych każdego przedsiębiorstwa. Wybór struktury kapitału z uwzględnieniem relacji kapitału pożyczkowego oraz kapitału własnego zależy zarówno od zewnętrznych, jak i wewnętrznych uwarunkowań z założeniem, że każde przedsiębiorstwo indywidualnie tworzy relacje kapitałowe. W artykule uwzględniono relacje kapitałowe przedsiębiorstw z wyróżnieniem struktury kapitałowej w wybranych polskich spółkach.

Cel - próba ustalenia optymalnej struktury kapitału wybranych spółek akcyjnych oraz jej weryfikacja w praktyce gospodarczej.

Metodologia - podstawą jest optymalizacja struktury kapitału z uwzględnieniem zróżnicowania udziału kapitału własnego i obcego, co wpływa w różnym stopniu na uzyskanie optymalnej struktury kapitału przedsiębiorstwa. Do ustalenia optymalnej struktury kapitału wykorzystano dodatek Excela, jakim jest Solver, za pomocą którego wyznaczono docelową strukturę. Zastosowano również metodę badań literaturową teoretyczno-empiryczną bazującą na krytycznej ocenie literatury oraz analizie rzeczywistej struktury wybranych spółek giełdowych.

Wynik - badania dla wybranych spółek przedstawiają w artykule strukturę kapitału oraz jej optymalizację. Na podstawie próby badawczej wyciągnięto wnioski, że niektóre spółki mają zbliżoną do optymalnej strukturę kapitału.

Oryginalność/wartość - artykułu przedstawiono za pomocą narzędzi ustalenia optymalnej struktury kapitału przy wykorzystaniu dostępnych danych finansowych oraz wybranych wskaźników finansowych.

\section{Factors of Optimal Capital Structure. Practical Verification}

KEYWORDS capital structure, cost of capital, company value, optimal capital structure

ABSTRACT The capital structure plays a significant role in each company's corporate financial strategy. The choice of the capital structure, taking into account the share of equities and liabilities, depends on external and internal conditions, provided that each company creates capital relations on its own. In the article, author put special emphasis on capital structure in selected polish companies.

Purpose - the attempt to discover optimal capital structure of chosen joint-stock companies and its verification in business practice.

Research methodology - is based on optimal capital structure taking into account the share of equity and liabilities which influence attaining optimal capital structure to a different degree. In order to find the optimal capital structure, the excel add -in was used, Solver, which enabled establishing the 


\begin{abstract}
final structure. The article is based on available literature referring to the field of research and the analysis of actual capital structure of chosen joint-stock companies.

Findings - present both, capital structure as well as, its optimization for the chosen companies in the article. Based on the conducted research one may assume that some of the companies have the capital structure close to the optimal one.

Originality/Value - the article has been created based on the available financial data and selected financial indicators with the tools used for creating optimal capital structure using
\end{abstract}

\title{
Wprowadzenie
}

Wybór struktury kapitału to istotny problem decyzyjny w każdym przedsiębiorstwie. W literaturze struktura kapitału rozpatrywana jest z uwzględnieniem wielu zagadnień związanych z ryzykiem finansowym, oceną kosztu kapitału, rozwiązaniami podatkowymi. W analizach uwzględnia się nie tylko czynniki decydujące o strukturze kapitału, lecz również związek z wartością rynkową przedsiębiorstwa oraz ekonomiczną.

Przedsiębiorstwo, w zależności od swoich potrzeb, wymaga różnych źródeł finansowania, które są niezbędne do zapewnienia płynności finansowej, ciągłości w prowadzeniu działalności oraz rozwoju. Potrzeby kapitałowe mogą być finansowane kapitałem własnym lub obcym. Źródła te cechują odmienne warunki pozyskania kapitału oraz koszty finansowe. Przedsiębiorstwo stara się pozyskać źródła finansowania, wybierając najkorzystniejsze warunki. Kryteria oraz czynniki uwzględniane przez podmioty gospodarcze są zróżnicowane, wybór zależy od zarządzających.

W literaturze scharakteryzowano wiele teorii dotyczących struktury kapitału. Teorie te głównie skupiają się na powiązaniu z teorią agencji, kosztami bankructwa czy też rozwiązaniami podatkowymi. W artykule przyjęto, że dominującą jest teoria substytucji.

Celem artykułu jest próba ustalenia zbliżonej do optymalnej struktury kapitału oraz weryfikacja wybranych spółek ze względu na korzyści, jakie pojawiają się z zadłużenia przedsiębiorstwa. Kapitał obcy stwarza możliwość wykorzystania tarczy podatkowej w przedsiębiorstwie, co wynika z tego, że odsetki stanowią koszt uzyskania przychodu w rozwiązaniach podatkowych. Powoduje to obniżenie efektywnego wykorzystaniu kosztu kapitału obcego oraz zmniejszenie podstawy opodatkowania.

\section{Struktura kapitału jako problem decyzyjny}

Teoria substytucji dowodzi, że istnieje optymalna struktura kapitału, która wpływa na wartość rynkową przedsiębiorstwa. Przedsiębiorstwo dąży do maksymalizacji wartości rynkowej oraz jak najniższych kosztów. W teorii struktury kapitału ważną rolę odgrywa teoria substytucji. Maksymalizacja wartości przedsiębiorstwa występuje dzięki dążeniu do optymalnej struktury kapitału. Do celu strategicznego, jakim jest maksymalizacja wartości przedsiębiorstwa, poszukiwane jest optimum kapitałowe. Przez prawidłowe zarządzanie finansami przedsiębiorstwo dąży do optymalnej struktury kapitału, przy jednoczesnym wzroście wartości przedsiębiorstwa (Grzywacz, 2012, s. 136-139).

Teoria substytucji koncentruje się przede wszystkim na wskazaniu optymalnej struktury kapitału, z uwzględnieniem odsetkowych korzyści podatkowych z kosztami trudności 
finansowych. Korzyści występujące z finansowania kapitałem obcym wiążą się z wykorzystaniem tarczy podatkowej, natomiast koszty te wynikają z możliwości wystąpienia trudności finansowych wskutek wzrostu ryzyka finansowego przedsiębiorstwa. Przedsiębiorstwo czerpie korzyści z kapitałów obcych w postaci odsetkowej tarczy podatkowej, to one powodują wzrost kosztów bankructwa i agencji. Koszty bankructwa pojawiają się, gdy przedsiębiorstwo nie jest w stanie regulować swoich zobowiązań wobec wierzycieli (Haugen, Senbet, 1978, s. 384). Powiązane są z powstaniem dodatkowych wydatków w spółce oraz powodują wzrost średniego kosztu kapitału oraz spadek rynkowych cen akcji (Jerzemowska, 1999, s. 100).

Optymalna struktura kapitału zapewnia ponadto maksymalną wartość rynkową przedsiębiorstwa przy jednoczesnym minimalizowaniu średniego ważonego kosztu kapitału (WACC) (Kołosowska, Tokarski, Tokarski, Chojnacka, 2014, s. 98). W teorii substytucji wyznaczany jest również optymalny poziom wskaźnika dźwigni finansowej, czyli relacji kapitału obcego do kapitału własnego (Fan, Titman, Twite, 2012, s. 43), przy czym nie są istotne źródła kapitału własnego (wewnętrzne lub zewnętrzne) (Łukasik, Naczyński, 2015, s. 76).

W wyborze struktury kapitału ważną rolę odgrywa jego koszt. Jest to kategoria ekonomiczna, która pozwala na uwzględnienie w decyzjach inwestycyjnych dochodów właścicieli oraz korzyści wierzycieli (Bielawska, 2014, s. 25). Z punktu widzenia kapitałodawców koszt kapitału rozumiany jest jako oczekiwana stopa zwrotu przy danym poziomie ryzyka (Fan, Titman, Twite, 2012, s. 48). Dla wierzycieli jest to wymagana stopa zwrotu, przy której są w stanie zaangażować swój kapitał w przedsiębiorstwo. Dla właścicieli natomiast jest to minimalna stopa zwrotu, jaką powinni uzyskać z zainwestowanego kapitału (Czekaj, Dresler, 2008, s. 91).

Koszt kapitału dłużnego ustalany jest na podstawie oprocentowania skorygowanego o efekt tarczy podatkowej. W celu ustalenia kosztu kapitału własnego wykorzystywany jest model CAPM. Określany jako model równowagi rynkowej, z uwzględnieniem takich czynników jak: stopa zwrotu wolna od ryzyka, premia za ryzyko rynku akcji oraz współczynnik $\beta$ (zob. Toni, 2016, s. 121). Najczęstszą metodą wykorzystywaną do modelu wyceny aktywów $\beta$ jest oszacowanie na podstawie modelu regresji pomiędzy stopą zwrotu z wybranej spółki a rynkową stopą zwrotu (Mugosa, 2015, s. 85).

Współczynnik $\beta$ przedstawia zmienność cen akcji analizowanego przedsiębiorstwa z uwzględnieniem zmienności całego indeksu rynkowego. W strukturze kapitału wpływa na wartość średnioważonego kosztu kapitału (WACC), wykorzystanego w gospodarce dla wyceny wartości przedsiębiorstwa oraz w koncepcji zarządzania wartością firmy.

W celu wyznaczenia optymalnej struktury kapitału niezbędne jest wyznaczenie współczynnika dźwigni finansowej. W literaturze opisano wiele definicji związanych z pojęciem dźwigni finansowej. W polskiej literaturze finansowej przytoczono definicję, według której dźwignia finansowa występuje, gdy przedsiębiorstwo zaciąga oprocentowane zobowiązania. Jej głównym celem jest podwyższenie wskaźnika rentowności kapitału własnego ROE w porównaniu z sytuacją, w której przedsiębiorstwo jest finansowane wyłącznie kapitałem własnym (Duliniec, 2011, s. 90). Z definicji można wyciągnąć wniosek, że celem wykorzystania przez przedsiębiorstwo kapitałów obcych jest wzrost stopy zwrotu z kapitału własnego (ROE).

Dźwignia finansowa wymaga zachowania warunku dodatniego efektu dźwigni finansowej. Warunkiem osiągnięcia pozytywnego efektu dźwigni finansowej jest to, że stopa zwrotu z całego zainwestowanego kapitału mierzonego wynikiem operacyjnym (ROIC) jest wyższa od 
kosztu kapitału obcego. Kapitał obcy rozumiany jest tutaj jako wykorzystanie dłużnych papierów wartościowych oraz kredytów i innych pożyczek oprocentowanych. (Duliniec, 2011, s. 88).

W praktyce osiągnięcie optymalnej struktury kapitału jest zadaniem bardzo trudnym. Pojawia się wiele zdarzeń niemożliwych do przewidzenia, które w znacznym stopniu utrudniają osiągnięcie optymalnej struktury kapitału. Ponadto nie istnieje jedna, stała, optymalna struktura kapitału dla wszystkich przedsiębiorstw, ponieważ sytuacja finansowa, indywidualne ryzyko operacyjne oraz otoczenie rynku, w którym działa, tworzy indywidualne szanse osiągnięcia optymalnej struktury.

Teoria substytucji potrzebuje weryfikacji w polskiej gospodarce rynkowej. Weryfikacja polega na próbie ustalenia zbliżonej do optymalnej struktury kapitału oraz porównania z rzeczywistą strukturą wybranych spółek. Celem przedstawionych badań jest ocena, czy wybrane przedsiębiorstwa w naszej gospodarce w pełni wykorzystują optymalną strukturę kapitału oraz w jakim stopniu wykorzystują dźwignię finansową w celu uzyskania wyższej stopy zwrotu z kapitału własnego (zgodnie z założeniami dodatniego efektu dźwigni finansowej). Do badań wykorzystano wybrane spółki z Giełdy Papierów Wartościowych w Warszawie.

\section{Praktyczna weryfikacja optymalnej struktury kapitału}

W analizie wykorzystano spółki z Indeksu WIG20 z Polskiej Giełdy Papierów Wartościowych w Warszawie. W pierwszej kolejności odrzucono spółki z sektora finansowego oraz ubezpieczeniowego. Następnie losowo wybrano spółki z różnych sektorów (paliwowego, energetycznego, odzieżowego i informatycznego). W analizie wzięły udział takie spółki, jak: Asseco Poland SA, CCC, PGE SA, PKN Orlen oraz LPP. Dla wszystkich analizowanych spółek ustalono zbliżoną do optymalnej strukturę kapitału na podstawie danych z 31.12.2015 roku.

Do analizy niezbędne jest wyznaczenie średnioważonego kosztu kapitału. W artykule przyjęto założenie do wyceny kosztu kapitału własnego zgodnego z modelem CAPM. Współczynnik $\beta$ obliczono dla poszczególnych spółek na podstawie tygodniowych prostych stóp zwrotu w okresie od 29 stycznia 2010 roku do 29 stycznia 2016 roku wraz z indeksem giełdowym WIG20.

Do ustalenia kosztu kapitału własnego dla wszystkich analizowanych spółek przyjęto stopę wolną od ryzyka jako obligacja dziesięcioletnia Skarbu Państwa. Obligacje dostępne są w sprzedaży od 1 kwietnia 2017 do 30 kwietnia 2017 roku, z oprocentowaniem 2,70\% (http://www.obligacjeskarbowe.pl/oferta-obligacji/obligacje-10-letnie-edo/edo0427/). Ze względu na brak danych w bilansie oraz rachunku zysków i strat związanym z wyznaczeniem kosztu kapitału obcego przyjęto oprocentowanie kredytu, jako stałe dla każdej spółki o wysokości 5,79\%1

Z powodu zmienności, jaka występuje w gospodarce, wystąpił problem z uzyskaniem stopy zwrotu z inwestycji dla portfela rynkowego. W celu próby ustalenia optymalnej struktury kapitału przyjęto stopę zwrotu w wysokości 10\% (Ranosz, 2017, s. 83), oszacowaną na podstawie WIG-u (Ranosz, 2017 s. 83).

Po uzyskaniu wszystkich niezbędnych danych obliczono koszt kapitału własnego na podstawie poniższego wzoru, a obliczenia przedstawiono w tabeli 1.

1 Wartość pozyskana z artykułu: https://www.bankier.pl/wiadomosc/Ta-sama-marza-inna-rata-kredytu-2339121.html. 
Tabela 1. Koszt kapitału własnego oraz obcego (\%)

\begin{tabular}{|c|c|c|c|c|c|c|}
\hline Rodzaj kapitału & $\begin{array}{c}\text { Asseco } \\
\text { Poland }\end{array}$ & CCC & PGE SA & PKN Orlen & ENEA SA & LPP \\
\hline Kapitał własny & 7,310 & 7,503 & 8,429 & 11,271 & 8,639 & 7,770 \\
\hline Kapitał obcy & 4,690 & 4,690 & 4,690 & 4,690 & 4,690 & 4,690 \\
\hline
\end{tabular}

Źródło: opracowanie własne.

W kolejnym etapie na podstawie kosztu kapitału własnego oraz obcego obliczono średnioważony koszt kapitału. W celu ustalenia optymalnej struktury kapitału posłużono się dodatkiem Excela - Solver. Do celów analizy wykorzystano następujące założenia:

- udział kapitału własnego do zobowiązań ma być większy bądź równy jedności,

- suma udziału kapitału własnego w pasywach oraz udziału długu w pasywach ma być równa jedności,

- kapitał własny wraz z długoterminowymi zobowiązaniami w pełni pokrywają aktywa trwałe.

Ponadto suma bilansowa pozostała bez zmian po wyznaczeniu zbliżonej do optymalnej struktury kapitału.

W tabeli 2 przedstawiono strukturę kapitału przed i po optymalizacji. Niektóre spółki cechuje zbliżona do optymalnej struktura kapitału - zaliczają się do nich CCC, PKN Orlen oraz LPP. Optymalizacja w tych spółkach niewiele zmieniła w średnioważonym koszcie kapitału, jak i przy wartościach kapitału własnego czy zobowiązań. Spółki te w pełni wykorzystują szanse, jakie daje im rynek finansowy, akceptując ryzyko w dłuższym okresie. Spółki te stawiają na rozwój, uwzględniając zmiany strukturalne. W przedsiębiorstwach tych zbliżony jest udział kapitału własnego oraz zobowiązań w sumie bilansowej. Taka struktura pozwala na minimalizowanie kosztów w przedsiębiorstwie, natomiast zwiększa ryzyko utraty płynności, co w konsekwencji może doprowadzić do bankructwa w przedsiębiorstwie.

Spółki PGE SA oraz Asseco Poland utrzymują strategię defensywną. Przedsiębiorstwa te starają się utrzymać wiarygodność oraz pozycję rynkową w aktualnej strukturze, minimalizując ryzyko oraz neutralizując zagrożenia. Celem ich strategii jest stabilizacja wartości ekonomicznej oraz rynkowej, wraz z przetrwaniem na rynku. Przedsiębiorstwa te dokonały wyboru strategii, która pozwala tak ukształtować strukturę kapitału, by uniknąć wszelkich zagrożeń płynących z rynku finansowego za sprawą struktury kapitałowej. Podmioty cechuje znaczny udział kapitału własnego w pasywach w porównaniu do zobowiązań. Spółki nie wykorzystują w pełni efektu dźwigni finansowej, które mogłyby ograniczyć koszty, na jakie narażone jest przedsiębiorstwo, natomiast poprzez zróżnicowanie źródeł finansowania spółki te utrzymują bezpieczną sytuację finansową. 


\begin{tabular}{|c|c|c|c|c|c|c|c|c|c|c|c|}
\hline & 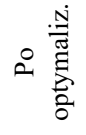 & $\begin{array}{l}\infty \\
\infty \\
\infty \\
\\
\infty \\
\\
-\end{array}$ & 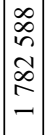 & $\begin{array}{l} \pm \\
\infty \\
n \\
n \\
\infty \\
\infty \\
-\end{array}$ & $\begin{array}{l}m \\
\underline{1} \\
n \\
0 \\
n \\
m\end{array}$ & in & $\begin{array}{l}8 \\
\therefore \\
i n\end{array}$ & $\vec{\sim}$ & $\underset{-}{8}$ & $\underset{8}{8}$ & $\underset{\stackrel{N}{a}}{\stackrel{+}{0}}$ \\
\hline$\exists$ & 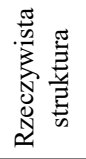 & 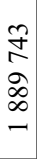 & 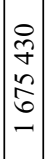 & $\begin{array}{l} \pm \\
\infty \\
n \\
n \\
\infty \\
- \\
-\end{array}$ & $\begin{array}{l}m \\
\Xi \\
n \\
b \\
n \\
m\end{array}$ & $\begin{array}{l}\overrightarrow{0} \\
\tilde{n}\end{array}$ & $\begin{array}{l}\text { के } \\
\text { bे }\end{array}$ & $\begin{array}{l}\stackrel{0}{2} \\
\stackrel{2}{r}\end{array}$ & 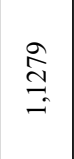 & $\begin{array}{l}0 \\
\infty \\
\infty \\
\infty \\
0\end{array}$ & 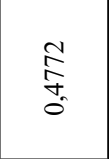 \\
\hline$\frac{\overline{0}}{\dot{D}}$ & 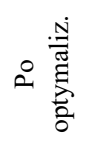 & $\begin{array}{l}\infty \\
\stackrel{+}{ } \\
\infty \\
\& \\
\dot{\sim} \\
\dot{\sim}\end{array}$ & 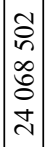 & 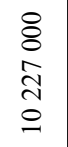 & 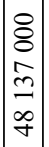 & $\begin{array}{l}8 \\
\text { in }\end{array}$ & $\begin{array}{l}8 \\
\text { in }\end{array}$ & $\begin{array}{l}n \\
\hat{n} \\
\infty \\
\infty\end{array}$ & 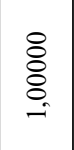 & \begin{tabular}{l}
8 \\
8 \\
\hdashline
\end{tabular} & $\frac{\infty}{\hat{a}}$ \\
\hline$\frac{Z}{a}$ & 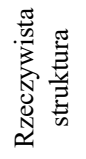 & 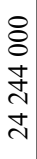 & 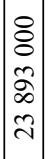 & 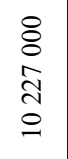 & 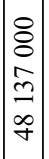 & $\begin{array}{l}0 \\
\text { ñ } \\
\text { in }\end{array}$ & $\begin{array}{l}\dot{b} \\
\stackrel{q}{q}\end{array}$ & $\begin{array}{l}n \\
n \\
\infty\end{array}$ & $\underset{0}{\stackrel{J}{0}}$ & $\begin{array}{l}\approx \\
\approx \\
\approx \\
\sigma\end{array}$ & $\begin{array}{l}\infty \\
\stackrel{\infty}{\hat{\sigma}} \\
\stackrel{0}{0}\end{array}$ \\
\hline & 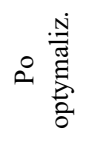 & $\begin{array}{l}2 \\
2 \\
\hat{2} \\
\grave{2} \\
0 \\
\text { r }\end{array}$ & 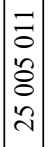 & 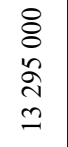 & $\mid \begin{array}{l}8 \\
8 \\
0 \\
2 \\
\\
\\
\end{array}$ & $\begin{array}{l}\vec{n} \\
\text { in }\end{array}$ & $\begin{array}{l}\stackrel{2}{a} \\
\dot{q}\end{array}$ & $\begin{array}{l}2 \\
2 \\
\sim\end{array}$ & $\stackrel{m}{\stackrel{n}{g}}$ & \begin{tabular}{l}
8 \\
\multirow{2}{0}{} \\
0 \\
0
\end{tabular} & $\underset{\square}{\circ}$ \\
\hline$\approx$ & 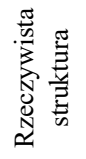 & 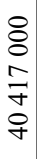 & 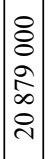 & 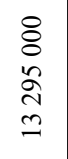 & 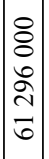 & $\begin{array}{l}\text { मे } \\
\text { బे }\end{array}$ & $\begin{array}{l}\stackrel{8}{0} \\
\dot{m}\end{array}$ & $\begin{array}{l}n \\
n \\
\sim\end{array}$ & 离 & $\begin{array}{l}\stackrel{0}{0} \\
\stackrel{1}{n} \\
0\end{array}$ & $\begin{array}{l}\tilde{2} \\
\text { ลे }\end{array}$ \\
\hline & 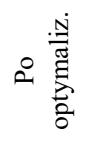 & $\begin{array}{l}8 \\
8 \\
0 \\
0 \\
0 \\
-\end{array}$ & \begin{tabular}{|c|}
8 \\
8 \\
0 \\
0 \\
0 \\
-
\end{tabular} & 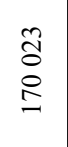 & 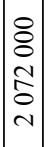 & $\begin{array}{l}8 \\
\therefore \\
i n\end{array}$ & $\begin{array}{l}8 \\
\therefore \\
\text { in }\end{array}$ & $\begin{array}{l}2 \\
8 \\
0 \\
0\end{array}$ & $\underset{8}{\circ}$ & $\stackrel{8}{8}$ & $\begin{array}{l}\overrightarrow{0} \\
\frac{0}{0}\end{array}$ \\
\hline J & 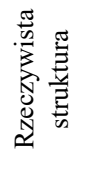 & 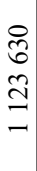 & 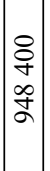 & 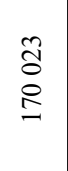 & 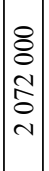 & $\begin{array}{l}\tilde{N} \\
\dot{n}\end{array}$ & $\begin{array}{l}\hat{\hat{y}} \\
\mathrm{f}\end{array}$ & ה్ & $\begin{array}{l}\infty \\
\infty \\
=\end{array}$ & $\begin{array}{l}\underset{f}{J} \\
\infty \\
0 \\
0\end{array}$ & $\frac{\Delta}{\stackrel{\Xi}{*}}$ \\
\hline $\begin{array}{l}\vec{\Xi} \\
\text { 言 }\end{array}$ & 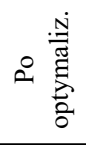 & \begin{tabular}{l}
$\infty$ \\
के \\
0 \\
\multirow{7}{f}{} \\
0
\end{tabular} & 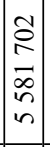 & 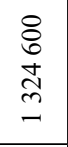 & $\begin{array}{l}8 \\
0 \\
\tilde{2} \\
0 \\
1 \\
1\end{array}$ & $\begin{array}{l}8 \\
\dot{H}\end{array}$ & $\begin{array}{l}8 \\
8 \\
\dot{f}\end{array}$ & 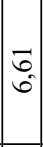 & $\begin{array}{l}\text { 今̃ } \\
\stackrel{2}{=}\end{array}$ & $\begin{array}{l}\widehat{\widehat{V}} \\
\infty \\
0 \\
0\end{array}$ & $\underset{-}{\stackrel{0}{0}}$ \\
\hline 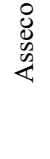 & 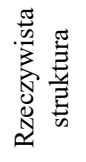 & $\begin{array}{l}8 \\
8 \\
y \\
y \\
\infty \\
\infty\end{array}$ & 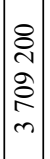 & 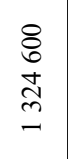 & 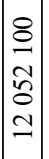 & $\begin{array}{l}\text { ते } \\
\text { gे }\end{array}$ & $\begin{array}{l}\infty \\
\stackrel{\infty}{\delta} \\
e^{2}\end{array}$ & 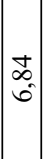 & 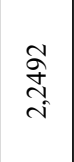 & $\underset{0}{\stackrel{+}{+}}$ & 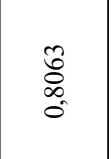 \\
\hline & $\begin{array}{l}\bar{N} \\
\vec{D} \\
\vec{D} \\
3\end{array}$ & 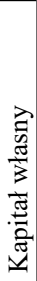 & 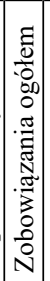 & 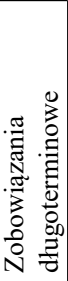 & 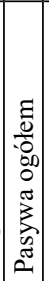 & 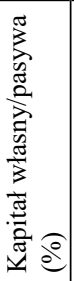 & 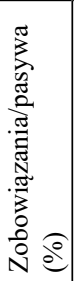 & $\mid$ & 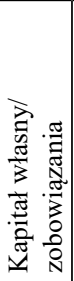 & 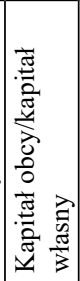 & 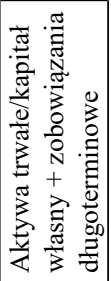 \\
\hline
\end{tabular}




\section{Podsumowanie}

W artykule próbowano uzasadniać rolę optymalnej struktury kapitału, znaczenie oraz wykorzystanie w przedsiębiorstwie optymalizacji struktury kapitału. Dokonano próby ustalenia odpowiedniej relacji kapitału w przedsiębiorstwie. Metodologia wykonana jest przez odpowiedni udział kapitału własnego oraz obcego w sumie bilansowej.

Analizując wybrane spółki kapitałowe oraz tworząc ich strukturę zbliżoną do optymalnej, zaproponowano prawidłowy udział finansowania kapitałem własnym oraz zobowiązaniami w zależności od średnioważonego kosztu kapitału oraz aktywów trwałych. Dla spółek wyznaczono proporcjonalny podział między kapitałem własnym a obcym, co może świadczyć o dość dużym ryzyku związanym z utratą płynności w przedsiębiorstwie, natomiast większą liczbę analizowanych spółek cechuje proporcjonalny podział kapitału, co może świadczyć o racjonalnym podejściu.

Duże spółki mają możliwość wykorzystania strategii ofensywnej, co skutkuje pełnym wykorzystaniem dźwigni finansowej, a to w konsekwencji doprowadza do wzrostu wskaźników rentowności. Przedstawione wyniki badań pozwalają na sformułowanie tezy, że niektóre analizowane przedsiębiorstwa mają optymalną strukturę, natomiast mniejsze spółki, nie mają dostępu do względnie niskiego oprocentowania kapitału obcego, co więcej nie mają wystarczającej zdolności kredytowej, by uzyskać optymalną strukturę za pomocą kapitału obcego.

W strategii finansowej przedsiębiorstw struktura kapitału odgrywa szczególną rolę, wpływając na stopień podejmowanego ryzyka finansowego. Poszukiwanie optymalnej struktury kapitałowej to jedna z najważniejszych decyzji uczestników rynku finansowego. Ważne jest więc pytanie, w jakim stopniu struktura kapitału powinna uwzględniać udział kapitału własnego, a w jakim kapitału obcego. W artykule zaprezentowano podstawowe elementy teorii struktury kapitału z próbą oceny jej wpływu na wartość rynkową przedsiębiorstw na polskim rynku kapitałowym.

Przeanalizowana optymalizacja na pewno wymaga udoskonalenia w postaci ryzyka bankructwa oraz podziału na zobowiązania długoterminowe oraz krótkotermiowe, lecz dla potrzeb weryfikacji optymalnej struktury kapitału jest wystarczający. Założenia przedstawione w artykule wydają się wystarczające dla potrzeb analizy.

\section{Literatura}

Bielawska, A. (red.) (2014). Nowoczesne zarządzanie finansami przedsiębiorstwa. Warszawa: C.H. Beck.

Czekaj, J., Dresler, Z. (2008). Zarządzanie finansami przedsiębiorstw. Warszawa: Wydawnictwo Naukowe PWN.

Duliniec, A. (2011). Finansowanie przedsiębiorstwa. Strategie i instrumenty. Warszawa: PWE.

Fan, J.P., Titman, S., Twite, G. (2012). An international comparison of capital structure and debt maturity choices. Journal of Financial and Quantitative Analysis, 47 (1), 23-56. DOI:10.1017/S0022109011000597.

Grzywacz, J. (2012). Kapital w przedsiębiorstwie i jego struktura. Warszawa: Wydawnictwo SGH.

Haugen, R.A., Senbet, L.W. (1978). The Insignificance of Bankruptcy Costs to the Theory of Optimal Capital. Structure. The Journal of Finance, 2 (33), 384.

Jerzemowska, M. (1999). Kształtowanie struktury kapitału w spótkach akcyjnych. Warszawa: Wydawnictwo Naukowe PWN.

Kołosowska, B., Tokarski, A., Tokarski, M., Chojnacka, E. (2014). Strategie finansowania działalności przedsiębiorstw. Wydawnictwo Wolters Kluwer. 
Łukasik, G., Naczyński, D. (2015). Rola struktury kapitału w kształtowaniu wartości przedsiębiorstwa (elementy teorii, doświadczenia praktyki). Ekonomika i organizacja gospodarki żywnościowej. Zeszyty Naukowe Szkoły Głównej Gospodarstwa Wiejskiego w Warszawie, 112, 76.

Mugosa, A. (2015). The determinants of capital structure choice: Evidence from Western Europe. Faculty of Economics, University of Montenegro, Republic of Montenegro.

Ranosz, R. (2017). Analiza struktury i kosztu kapitału w przedsiębiorstwach górniczych. DE GRUYTER OPEN.

Vide T. (2016). Does it pay to be good? An analysis of vice and virtue stock performance in the Eurozone. Journal of Banking and Financial Economics, 2 (6), 121.

\section{Cytowanie}

Piątkowska, J. (2017). Czynniki optymalizacji struktury kapitału. Praktyczna weryfikacja. Współczesne Finanse. Teoria i Praktyka, 1 (2), 45-52. DOI: 10.18276/wf.2017.1-05. 